\title{
О РИСКОВОСТИ ДОГОВОРА СТРАХОВАНИЯ ПО ЗАКОНОДАТЕЛЬСТВУ РОССИЙСКОЙ ФЕДЕРАЦИИ И РЕСПУБЛИКИ КАЗАХСТАН
}

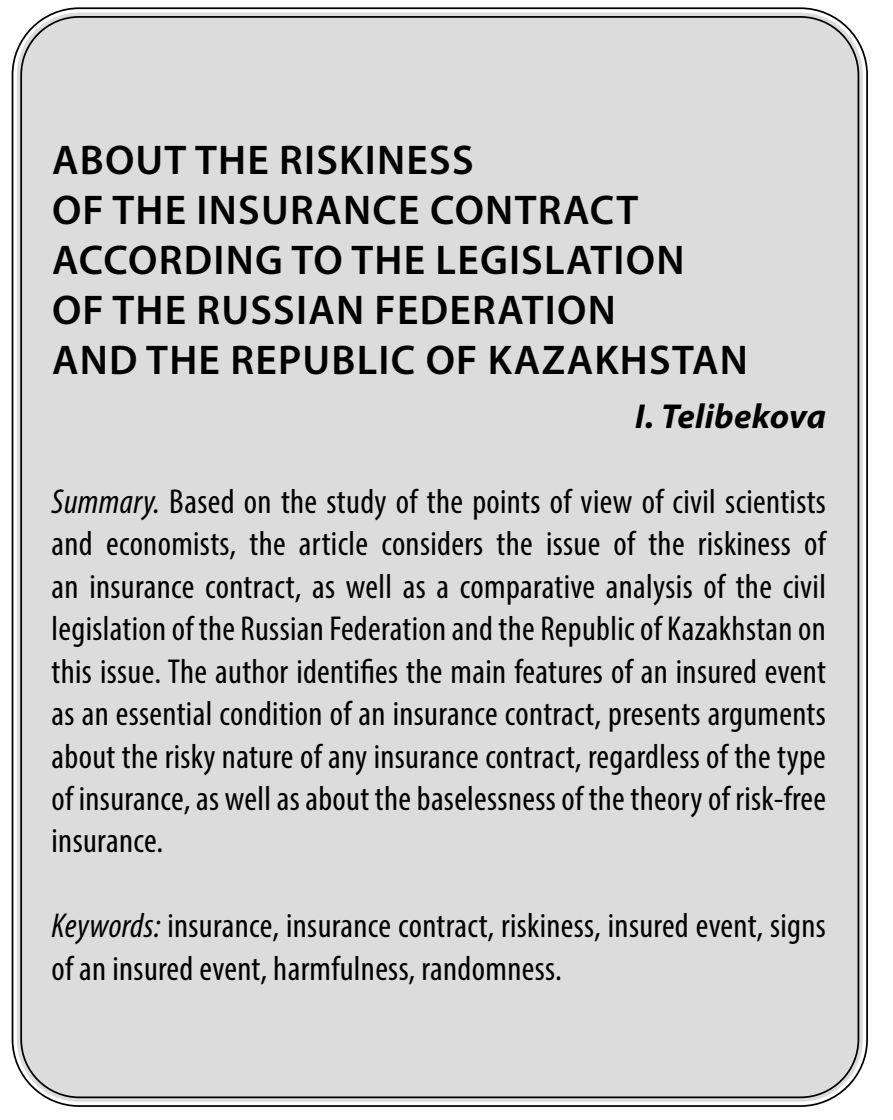

B данной статье мы на основе сравнительного анализа правового регулирования страхования в Российской Федерации (далее - РФ) и в Республике Казахстан (далее - РК) рассмотрели один из ключевых признаков договора страхования - признак рисковости.

Любой договор не может быть заключен, если стороны не пришли к соглашению по поводу существенных условий. Одним из существенных условий договора страхования является условие о страховом случае, которое характеризуется признаком рисковости. Отметим, что многие правоведы при рассмотрении этой характеристики договора страхования, ошибочно связывают ее с признаками страхового случая, к которым относят только негативные последствия, которые он несет. К ним они причисляют вредоносность, вероятность, случайность, нежелательность страхового случая. При этом чаще всего они ссылаются на неопределенность наступления самого страхового случая, либо на неопределенность тех негативных последствий
Телибекова Ирина Мендигереевна

К.ю.н., Российская академия интеллектуальной собственности, Москва irina67.kz@mail.ru

Аннотация. В статье на основе изучения точек зрения ученых-цивилистов и экономистов рассмотрен вопрос о рисковости договора страхования, а также проведен сравнительный анализ гражданского законодательства Российской Федерации и Республики Казахстан по данному вопросу. Автором обозначены основные признаки страхового случая, как существенного условия договора страхования, представлены доводы о рисковом характере любого договора страхования, вне зависимости от вида страхования, а также о безосновательности теории безрискового страхования.

Ключевые слова: страхование, договор страхования, рисковость, страховой случай, признаки страхового случая, вредоносность, случайность.

и убытков, которые он несет. Именно об этом указывает Т.И. Султонова: «договор страхования смоделирован таким образом, что с момента заключения договора возникает неопределённость относительно конечного правового результата для каждой из его сторон» [1].

О неопределенности в договоре страхования говорит и Н.Ю. Хузина. По мнению автора, «договор страхования смоделирован таким образом, что с момента заключения договора возникает неопределённость относительно конечного правового результата для каждой из его сторон» [2]. Действительно, для сторон договора страхования ситуация со страховым случаем остается неопределенной в течение всего срока действия заключенного договора страхования. Исход договора страхования всегда зависит от страхового случая, тем самым обусловливая рисковость этого договора. В тоже время российский законодатель, указывая в ст. 942 Гражданского кодекса РФ (далее - ГК РФ) на необходимость достижения соглашения по поводу страхового случая между сторонами при заключении 
договора имущественного и личного страхования, все же не дает понятия страхового случая в самом ГК [3]. Понятие страхового случая дано в ч. 2 ст. 9 Закона РФ «Об организации страхового дела в Российской Федерации» от 27.11.1992 г. № 4015-1 (далее - ЗРФ Об организации (Д), где указано, что «Страховым случаем является совершившееся событие, предусмотренное договором страхования или законом, с наступлением которого возникает обязанность страховщика произвести страховую выплату страхователю, застрахованному лицу, выгодоприобретателю или иным третьим лицам» [4].

В отличие от российского законодателя в ст. 817 Гражданского кодекса Республики Казахстан (далее ГК РК) представлено понятие страхового случая, как события, с наступлением которого договор страхования предусматривает осуществление страховой выплаты [5]. То есть, несмотря на то что в ГК РК не выделена самостоятельная норма о существенных условиях данного гражданско-правового обязательства, казахстанский законодатель посчитал необходимым ввести в ГК определение страхового случая.

В ч. 1 ст. 9 ЗРФ Об организации СД определено понятие страхового риска, которым является предполагаемое событие, на случай наступления которого проводится страхование [4]. Однако почему-то российский законодатель ч. 2 данной статье указывая событие, рассматриваемое в качестве страхового риска, включает императивную формулировку о необходимости таких признаков, как вероятность и случайность его наступления. Здесь мы не можем полностью согласиться с российским законодателем. Ведь, если в качестве страхового случая будет предусмотрено событие, не несущее негативные последствия, то при наличии признака вероятности, такой признак как случайность наступления просто исключается.

Примечательно, что исходя из содержания ЗРФ Об организации СД страховой случай должен быть случаен, а значит вредоносен и не желателен для страхователя или застрахованного лица, что относится напрямую только к имущественному страхованию, где у страхователя есть имущественный интерес в страховании. При этом в случае отсутствия интереса в страховании договора страхования является недействительным, о чем гласит ст. 930 ГК РФ [3].

О том, что страхователь может застраховать имущественные интересы, связанные с дожитием граждан до определенных возраста или срока либо наступлением иных событий в жизни граждан, а также с их смертью (страхование жизни), и с причинением вреда здоровью граждан, а также с их смертью в результате несчастного случая или болезни (страхование от несчастных случаев и болезней), российский законодатель указал в ст. 4 ЗРФ Об организации СД [4]. Следует обратить внимание и на то, что при имущественном страховании между страховым интересом страхователя в сохранении имущества, страховым случаем, указанном в договоре и страховым риском прослеживается связь. Каким же образом она устанавливается при личном страховании?

В казахстанском законодательстве в ст. 807 ГК РК закреплено, что могут быть застрахованы «любые имущественные интересы граждан и юридических лиц, в том числе связанные с: 1) дожитием граждан до определенного возраста или срока, установленного договором страхования, смертью, наступлением определенных событий в жизни граждан; 2) причинением вреда жизни и здоровью граждан в результате несчастных случаев и иных событий, заболеваний; 3) владением, пользованием и распоряжением имуществом; 4) обязанностью возместить вред, причиненный другим лицам, в том числе в результате нарушения договора (обязательств)» [5].

Что касается страхового риска, в Законе РК «О страховой деятельности» от 18.12.2000 г. № 126-ІІ в п. 23-1 ст. он определен как вероятность наступления страхового случая [6]. Здесь мы также не можем согласиться в полной мере с казахстанским законодателем, так как, например, при страховании на дожитие, страхование всегда есть вероятность наступления определенного договором возраста, и наступление этого страхового случая ожидаемо. Скорее всего, казахстанскому законодателю следовало бы с учетом этого изменить формулировку данной нормы. Кроме того, С.С. Бочкова справедливо замечает, что так же, как и в казахстанском законодательстве, в ГК РФ «рисковый характер страхового случая предусмотрен исключительно для имущественного страхования» [7]. В связи с этим думается, что и российскому законодателю не следует упускать из виду это обстоятельство.

В науке гражданского права по поводу признаков страхового случая известны и другие мнения. Так, М.Н. Гекко подразделяет страховые случаи «на рисковые, которые являются носителями признаков вредоносности, вероятности, случайности и безрисковые (облигаторные), лишенные указанных признаков... и, соответственно, договоры страхования - на рисковые и безрисковые» [8]. В качестве примера безрискового договора страхования автор приводит договор страхования на дожитие, где страховым случаем обозначен срок окончания действия договора (облигаторный страховой случай). По этому поводу И.Э. Шинкаренко указывает, что рисковые обстоятельства бывают 
ожидаемые и непредвиденные [9]. И мы думаем, что следует согласиться с данной точкой зрения, поскольку в отличие от М.Н. Гекко, И.Э. Шинкаренко все страховые случаи относит к рисковым, подразделяя их на обстоятельства, которые ожидаемые страхователем, и на те, время наступления которых для страхователя и страховщика неизвестно.

При этом доводы о безрисковых договорах страхования учеными мотивируются ожидаемостью страхового случая, не случайным, а обязательным его наступлением, его невредоносностью (отсутствием негативных последствий) и тем, что страхователь предвидит наступление страхового случая в будущем: «нельзя абсолютизировать рисковый характер договора страхования, поскольку существует обеспечительное (безрисковое) страхование, в котором рисковый момент либо значительно смягчен, либо отсутствует полностью» [10, С. 223].

Как указывают ученые, «традиционно считается, что событие, рассматриваемое в качестве страхового случая, должно обладать тремя признаками: вредоносности, вероятности и случайности наступления. Однако наличие такого вида личного страхования, как страхование жизни (накопительного страхования), заставляет пересмотреть общую концепцию страхового случая [Там же, С. 60]. При этом авторы ссылаются на свадебное страхование, при котором в качестве страхового случая выступает сама свадьба. Это событие рассматривается ими как невредоносное и не несущее негативные последствия. Таким образом, как практика страхового дела, так и страховое законодательство допускают возможность существования страховых случаев, не обладающих признаком вредоносности.

По поводу такого признака страхового случая, как случайность его наступления в научной среде также бытует мнение о том, что существуют такие виды личного страхования (накопительное страхование), для которых характерна неизбежность наступления события, предусмотренного в качестве страхового случая. По мнению ученых, страховая конструкция при этих видах страхования основана на том, что страховой случай неизбежен. При этом стороны не только знали в момент заключения договора, но и договорились заранее по поводу страхового случая. В связи с этим ученые видят необходимость в пересмотре, не только отдельных научных концепций страхования, но и страхования в целом. Кроме того, ученые полагают, что наличие в практике страхового дела и в страховом законодательстве «безрискового» страхования, при котором, по их мнению, страховой случай лишен признаков случайности и вредоносности, перед наукой гражданского права существует необходимость переосмысле- ния сущности и характерных признаков страхования в целом, и признаков страхового случая в частности. В то же время в науке имеется противоположная точка зрения, согласно которой «страховой случай может произойти, но может и не произойти» [11, С. 521].

Мы несколько иначе подходим к рассмотрению вопроса о рисковости договора страхования, то есть с другого ракурса. Если страховой случай неслучаен, невредоносен и позитивен, то нет риска для страхователя, ради которого он прибегает к услугам страхования, а также для страховщика. Не отказываясь от предложенной учеными классификации признаков страхового случая, полагаем, что нет необходимости делить в зависимости от нее все договоры страхования на рисковые и безрисковые. Это обусловлено тем, что даже если страховые случаи ожидаемы, предсказуемы и страхователь предвидит их наступление, то они могут случайно не наступить в силу объективных или субъективных обстоятельств. Например, вступление в брак или достижение определенного возрастного рубежа представляют собой страховые случаи, которые не являются вредоносными, наступают не случайно и не несут негативных последствий для страхователя. Страхователь, как правило, ждет и желает их наступления. Но указанные события могут случайно не наступить вследствие несчастного случая.

Предположим, страхователь заключил со страховщиком договора добровольного личного страхования, в котором в качестве страхового случая указал окончание высшего учебного заведения (далее - ВУЗ). Однако в силу различных обстоятельств, как объективных (лишение ВУЗа лицензии, прекращение деятельности ВУЗа как юридического лица), так и субъективных (недопуск к экзаменам, неоплата обучения и т.д.), страховой случай может не наступить. Как видим, страховой случай в виде окончания ВУЗа носит позитивный характер, он ожидаем страхователем, и его наступление для него желательно. Но данный страховой случай не всегда может наступить, то есть риск его ненаступления.

Рассмотрим другой пример. В период развитого социализма и времен монополии Госстраха имело место страхование родителями своих детей до достижения ими совершеннолетия. В соответствии с данным договором страхования родитель осуществлял страхование своего несовершеннолетнего ребенка, который при достижении им восемнадцать лет получал страховое возмещение (выплату). Данный договор имел конструкцию договора с участием третьего лица, а именно в пользу третьего лица - застрахованного ребенка. Страховой случай здесь также желателен, ожидаем, позитивен и не несет негативных последствий ни для страхователя, ни для застрахованного лица. Но, как 
и в первом примере, данный страховой случай - достижение совершеннолетия, также мог не наступить в силу объективных и субъективных причин.

Такая категория как «случайность» страхового случая может быть сопряжена с его наступлением или ненаступлением. По мнению основоположников казахстанской цивилистики «страховой случай может произойти, но может и не произойти» [Там же]. То есть, если это вредоносный страховой случай, несущий негативные последствия, то возможна «случайность его наступления», которая нежелательна для страхователя, застрахованного. Если это невредоносный страховой случай, наступление которого не приносит страхователю каких-либо негативных последствий, то даже при его предсказуемости, ожидаемости и закономерности возможна «случайность его ненаступления».

По этому поводу справедливо замечание А.К. Шихова о том, что при страховании «возможность ненаступления каких-либо ожидаемых событий или отклонение каких-либо величин от ожидаемых значений также ориентированы на потери... События же эти проявляются как следствие (результат) взаимосвязи и взаимодействия множества составляющих материального мира, каждого человека, объединения людей, действующих в них и между ними сил...Естественным результатом взаимодействия сил может быть их уравновешенность, т.е. известное событие может не произойти в определенный период времени» [12, С. 27].

Получается, что предсказуемое событие может не наступить по случайному стечению обстоятельств. Действительно, страхование, как личное, так и имущественное, всегда зависит от объективных и субъективных обстоятельств, от субъективной и объективной вероятности. Примечательна точка зрения А.Г. Гойхбарга, который считал, что «при лихорадочном темпе нашей жизни, при массе грозящих на каждом шагу неожиданностей, неожиданностей для отдельного лица, но в совокупности своей содержащих элемент закономерности,- при всех этих обстоятельствах никто не уверен в завтрашнем дне, никто не ведает, что станется с ним самим, с его имуществом, с его близкими или лицами, которыми он по тем или иным многосложным причинам интересуется» [13, С. 761-770]. Это мнение А.Г. Гойхбарга, которое и на сегодняшний день остаётся актуальным, подтверждает наши доводы о том, что рисковость договора страхования следует рассматривать с другого ракурса.

Вячеславов А.В. и Константиниди А.В. по поводу алеаторности договора придерживаются следующей позиции: «алеаторность проявляется двояко. Страхователь, уплачивая страховую премию, не знает, получит ли он или лицо им управомоченное, страховое вознаграждение, а если получит, то при продолжительности взноса им премий страховщику покроет ли полученное им страховое вознаграждение уплаченные им премии. В свою очередь, страховщик не знает, придется ли ему вообще выплачивать страховое вознаграждение, или, по крайней мере, он не знает времени и объема выплаты этого вознаграждения» [14, С. 14-15].

Нам представляется неверным то, что рисковость договора страхования ставится в зависимость от его признаков (вероятности, случайности и предсказуемости). Страховой случай может наступить или нет вне зависимости от того, является ли он вредоносным или нет. В этом, по нашему мнению, и заключается рисковость любого договора страхования.

Таким образом, договор страхования является рисковым (алеаторным), а страховые случаи можно разделить на вредоносные и невредоносные. Вредоносные страховые случаи нежелательны для кредитора (страхователя) и могут повлечь за собой негативные последствия как для страхователя, так и для его имущества. Невредоносные страховые случаи, как правило, ожидаемы кредитором (страхователем), и несут позитивные последствия.

Согласно нашей точке зрения все договоры страхования являются рисковыми в силу того, что его стороны, заключая договор страхования, не знают, наступит страховой случай или нет. Если при заключении договора страхования не предполагается риск наступления или ненаступления страхового случая, который является особенностью данного вида обязательства, то незачем заключать этот договор, так как осуществление страхования без какого-либо риска не будет иметь смысла, который собственно, и заложен в его основу.

Это, в свою очередь означает, что существование страхования без риска (безрискового страхования) не обосновано. Мы считаем, что договор безрискового страхование невозможен. Нам представляется неверным то, что рисковость договора страхования ставится в зависимость от его признаков (вероятности, случайности и предсказуемости). Страховой случай может наступить или нет вне зависимости от того, является ли он вредоносным или нет. В этом, по нашему мнению, и заключается рисковость любого договора страхования. Если нет риска, то незачем прибегать к услугам страхования. Если страховой случай предвиден, невредоносен и позитивен, то его наступление ожидаемо, страхователь или застрахованное лицо желает, чтобы страховой случай наступил. Но нет вероятности, что страховой случай обязательно наступит. В этом и заключается риск для страховщика и для страхователя. 
Именно поэтому последний и прибегает к услугам страхования.

В итоге, мы полагаем, что договор страхования всегда является рисковым, поскольку всегда есть вероятность наступления или ненаступления страхового случая. Нам представляется, что, если страховой случай является вредоносным, несущим негативные последствия, то возможна «случайность его наступления». Если это невредоносный страховой случай, наступление которого не приносит страхователю каких-либо негативных последствий, то даже при его предсказуемости, ожидаемости, неизбежности возможна «случайность его ненаступления».

\section{ЛИТЕРАТУРА}

1. Султонова Тахмина Истамовна. Регулятивное значение случая в алеаторных договорах // Научный журнал КубГАУ. 2014. № 100. URL: https:// cyberleninka.ru/article/n/regulyativnoe-znachenie-sluchaya-v-aleatornyh-dogovorah (дата обращения: 21.07.2021).

2. Хузина Наталия Юрьевна. Договор страхования как один из видов алеаторных сделок // E-Scio. 2021. № 2 (53). URL: https://cyberleninka.ru/article/n/ dogovor-strahovaniya-kak-odin-iz-vidov-aleatornyh-sdelok (дата обращения: 21.07.2021).

3. Гражданский кодекс Российской Федерации (часть вторая) от 26.01.1996 г. № 14-Ф3. URL: http://www.consultant.ru/document/cons_doc_LAW_9027/f9 7fa76d258f4b035ab80b1e8926c01fa436807d/ (дата 0бращения 21.07.2021).

4. Закон РФ «0б организации страхового дела в Российской Федерации» от 27.11.1992 г. № 4015-1. URL: http://www.consultant.ru/document /cons_doc_ LAW_1307/ (дата обращения: 21.07.2021).

5. Гражданский кодекс Республики Казахстан (Особенная часть) от 01.07.1999 г. № 409-I. URL: https://online.zakon.kz/Document/?doc_id=1013880\#pos= 3284;-54 (дата обращения: 21.07.2021).

6. Закон PK «0 страховой деятельности» от 18.12.2000 г. № 126-II. URL: https://online.zakon.kz/Document/?doc_id=1021136\#pos=243;-46 (дата 06 paщения: 21.07.2021).

7. Бочкова Светлана Сергеевна. К вопросу о роли страхового интереса в страховом обязательстве // 0бразование и право. 2020. № 4. URL: https:// cyberleninka.ru/article/n/k-voprosu-0-roli-strahovogo-interesa-v-strahovom-obyazatelstve (дата обращения: 21.07.2021).

8. Гекко М.Н. Договор страхования по законодательству Республики Казахстан: автореф. на соиск. уч. степ.к.ю.н.: 12.00.03. - Алматы, 2005.— 33 с.

9. Шинкаренко И.Э. Страхование ответственности: Справочник. - М.: Финансы и статистика, 1999. — 352 с.

10. Худяков И.А., Демидова Г.С., Худяков А.А. Основы страхового права: Учебное пособие. Челябинск: ЮУрГУ, 2004. - 320 с.

11. Гражданское право: Учебник для вузов (академический курс). / Отв. ред.: М.К. Сулейменов, Ю.Г. Басин. НИИ частного права КазГЮу.—-Алматы. 2002. T. II. -624 c.

12. Шихов А.К. Страхование: Учебное пособие для вузов. - М.: ЮНИТИ-ДАНА, 2000. - 431 с.

13. Гойхбарг А.Г. Единое понятие страхового договора. // Право. — 1914. — № 10. — С. 761-770.

14. Вячеславов А.В., Константиниди А.В. Вопросы страхования (для предпринимателей): Учебное пособие. Московский государственный институт радиотехники, электроники и автоматики (технический университет). - М.: 2002. - 60 c.

( ) Телибекова Ирина Мендигереевна (irina67.kz@mail.ru ). Журнал «Современная наука: актуальные проблемы теории и практики» 